\title{
Invertebrate fossils from cave sediments: a new proxy for pre-Quaternary paleoenvironments
}

\author{
O. T. Moldovan ${ }^{1}$, A. Mihevc ${ }^{2}$, L. Miko ${ }^{3}$, S. Constantin ${ }^{4}$, I. N. Meleg ${ }^{1}$, A. Petculescu ${ }^{4}$, and P. Bosák ${ }^{2,5}$ \\ ${ }^{1}$ Department of Cluj, "Emil Racoviţă” Institute of Speleology, Clinicilor 5, 400006 Cluj-Napoca, Romania \\ ${ }^{2}$ Karst Research Institute, SRC SASA, Titov trg. 2, Postojna, Slovenia \\ ${ }^{3}$ European Commission, DG Environment, Av. de Beaulieu 5, 1160 Auderghem, Brussels, Belgium \\ 4"Emil Racoviţă” Institute of Speleology, Frumoasă 31, 010986 Bucureşti, Romania \\ ${ }^{5}$ Institute of Geology AS CR, v. v. i., Rozvojová 269, 16500 Praha 6, Czech Republic
}

Received: 18 March 2011 - Published in Biogeosciences Discuss.: 30 March 2011

Revised: 14 June 2011 - Accepted: 24 June 2011 - Published: 11 July 2011

\begin{abstract}
Five samples of clastic sediments from interior cave facies taken in three Slovenian relic caves (Trhlovca, Račiška pečina, and a cave in Čnnotiče Quarry, Classical Karst, SW Slovenia) provided invertebrate fossil remains. Most of them belong to Oribatida but sparse individuals of Cladocera and insects were also identified. They represent the first pre-Quaternary invertebrate fossils found in sediments of continental temperate climate. The Pliocene/Pleistocene age of the sediments was determined by paleomagnetic dating chronologically calibrated by micromammal biostratigraphy. Invertebrate fossils could be validated as new proxy for the study of cave sediments due to their suitability for ecological and paleogeographic correlations in caves and outside the caves. They also bring additional information about cave formation and karst hydraulic regime in the area. Although the number of remains was very low, it is evidence that climatic conditions in caves allow a better preservation of fossil remains of some groups as compared to most of the surface habitats. This may open a new direction in the study of cave sediments.
\end{abstract}

\section{Introduction}

Cave sediments preserve the geological and paleoenvironmental past (Horáček and Bosák, 1989) as well as biological and anthropological information (e.g., Kukla and Ložek, 1958; Horáček and Ložek, 1988; Bosák et al., 1989;

Correspondence to: O. T. Moldovan (oanamol@hasdeu.ubbcluj.ro)
Sasowsky and Mylroie, 2004). This is of special importance for the terrestrial (continental) history, where correlative sediments are mostly missing (Horáček and Bosák, 1989), which is the case of the studied karst region. Cave sediments are formed in place in caves, or are allochthonous in origin (Kyrle, 1923; Kukla and Ložek, 1958). Two contrasting facies can be distinguished among cave environments (Kukla and Ložek, 1958). The entrance facies includes fine-grained sediments transported from the vicinity of the cave by wind, water and slope processes. It represents the most valuable section of the cave from a stratigraphic point of view as it may contain datable archeological and paleontological remains that are protected from surface erosion, weathering and biochemical alteration (cf. Ford and Williams, 1989, 2007). The interior facies develops in those parts of the cave that are more remote from the surface. A dominant part of sediments belonging to the interior facies form in vadose conditions. Sedimentary sequences here are extensive, consisting of fluvial gravels and sands overlain by flood or injecta deposits of laminated silts and clays often intercalated by speleothems. They may also contain dejecta, colluvial material and outer clastic sediments (including marine ones), often re-deposited and/or injected for longer distances within the cave (cf. Ford and Williams, 1989, 2007). Most of the sediments result from material carried by (1) sinking streams and (2) gravity-driven infiltration from the surface (e.g., Ford and Williams, 1989; Brinkman and Reeder, 1995; White, 2007). Due to the dynamic environment of cave interiors and periodicity of events, sedimentary sequences often represent a series of depositional and erosional events (sedimentary cycles). These are separated by unconformities (breaks in deposition), which may

Published by Copernicus Publications on behalf of the European Geosciences Union. 
represent periods of substantial duration, and the erosional phases may be of much longer duration that the depositional events (e.g., Bosák, 2002, 2008; Bosák et al., 2003). Such sediments reflect past fluvial or lacustrine conditions within the cave. Distinct sequences of clastic sediments may be caused by changes in water volume and velocity, sediment source, surface weathering conditions and depositional conditions that are a function of climate change. Moreover, specific topoclimatic features of the cave environments delay the destruction processes of fossil remains (Sasowsky and Mylroie, 2004; Polk et al., 2007). Therefore, many types of information can be well preserved in the underground, such as: (1) the above-ground source (which may no longer be found on the surface), (2) the environmental evolution on the surface, including information on past vegetation and land use which is not preserved in fast-changing surface soils (Kukla and Ložek, 1958; Bottrell, 1996; Courty and Vallverdu, 2001; Panno et al., 2004; Polk et al., 2007), (3) the sub-surface depositional processes (Kukla and Ložek, 1958), and (4) the long-lasting general evolution of the sub-surface and surface karst (cf. Zupan Hajna et al., 2008b).

In karst areas, the evolution of the surface landscape is recorded inside the caves; lowering of the base level shifts active speleogenesis to lower elevations, and the overlying passages are subsequently abandoned and filled by sediments. Clastic sediments, sometimes intercalated with chemical precipitates, transported from the surface through the caves are frequently preserved unaltered for millions of years, providing different types of information (Bosák et al., 1998, 2003; Sasowsky, 2007). Although the recognition that cave sediments can reflect and conserve paleoclimatic data is old (Kukla and Ložek, 1958 and literature herein), the scientific interest in paleoclimatic record from clastic cave deposits developed only in the past decades (see summary of White, 2007). Mostly fossil vertebrate remains have been identified in clastic cave sediments and used to characterize environmental conditions, or used as paleoclimate proxies. Speleothems have been broadly utilized as paleoclimatic proxies using stable isotopes in combination with numerical dating, palynology and sedimentological features of clastic cave sediments (Bastin, 1978; Bastin et al., 1986 among others). Environmental studies of cave sediments, especially those of the entrance facies, have been also carried out using different kinds of proxies; e.g., charcoal, sediment pollen and coprolite pollen (Carrión et al., 1992a, b, 1995, 1997, 2005; Finlayson et al., 2008), stable carbon isotopes of organic matter (Turney et al., 2001), pesticide content derived from agricultural pollution (Bottrell, 1996), the presence of a certain vegetation type (Panno et al., 2004), the fulvic acid fraction of the organic matter (Polk et al., 2007), magnetic mineral properties (e.g., Elwood et al., 1996; Sroubek et al., 2001), or mollusks in cave archeological sites, etc. Other studies that focused on recent cave sediments as a proxy for the environmental changes on the surface were specifically linked to land-use (Polk et al., 2007). Only a single paper (Polyak et al., 2001) mentioned the discovery of twelve species of oribatid mites in two Holocene stalagmites from New Mexico, which were integrated in a paleoclimatic study.

Our study represents the first attempt to identify and study fossil invertebrates in clastic sediments from the interior cave facies and to discuss their possible use as biological proxies in paleoenvironmental studies. Similar methods and proxies applied to other sedimentary deposits, such as lakes, seas and lotic environments, can also be applied to cave sediments in order to obtain information on paleoclimate and paleoenvironmental conditions at the time of sediment deposition. Surface sedimentary deposits, especially lacustrine ones, represent paleoecological archives of plant macrofossils, pollen, algae and fossil invertebrates. Paleolimnology has developed as a multidisciplinary science especially in the last two decades using physical, chemical and biological proxies preserved in lake sediments (Luoto, 2009). The structure and the composition of fossil assemblages (we prefer the term fossil, as proposed by Erickson and Platt, 2007, to "subfossil") vary in response to changes in the environment, reflecting past climate, nutrient conditions, oxygen content, $\mathrm{pH}$, pollution or ecological interactions (Luoto, 2009). The cladocerans (Crustacea; Rautio, 2007), chironomids (Diptera; Walker, 2001), and ostracods (Crustacea; Holmes, 2001) are the most commonly used invertebrate remains in paleolimnology. It is not difficult to identify them to a species level, and their autoecology is well known (Luoto, 2009). Other remains, such as protozoans, bryozoans, oribatid mites (Acarina), insects and mollusks, are rather rarely used (Smol, 2002). Until recently, invertebrate fossils have mostly been studied in lake sediments and only few of them in fluviatile environments (Gandouin et al., 2006; Engels et al., 2008; Howard et al., 2009).

Clastic sedimentary sequences belonging to the interior cave facies were carefully selected for a first attempt to find fossil invertebrates in caves. Sedimentary sections well dated by magnetostratigraphy and paleomagnetic dates were calibrated by biostratigraphy (Horáček et al., 2007; Zupan Hajna et al., 2008b, 2010). The selected caves are located in the Classical Karst, the part of the Slovene Dinaric region of Kras (southeastern Europe). Shallow marine Dinaric Carbonate Platform deposits (Jurassic to Paleogene) are covered by Eocene flysch siliciclastics. Both units are overthrust in tectonically complicated structures (Placer, 1999). No postEocene marine or terrestrial deposits are preserved on the surface now. Surface morphology and karst evolved during a single post-Eocene karst period. Speleogenesis was later followed by cave infilling processes (partial or complete fossilization) that started at the Oligocene/Miocene boundary as indicated by fission track (AFTA) and paleontologicallycalibrated paleomagnetic data from some of the studied sites (Zupan Hajna et al., 2010). 

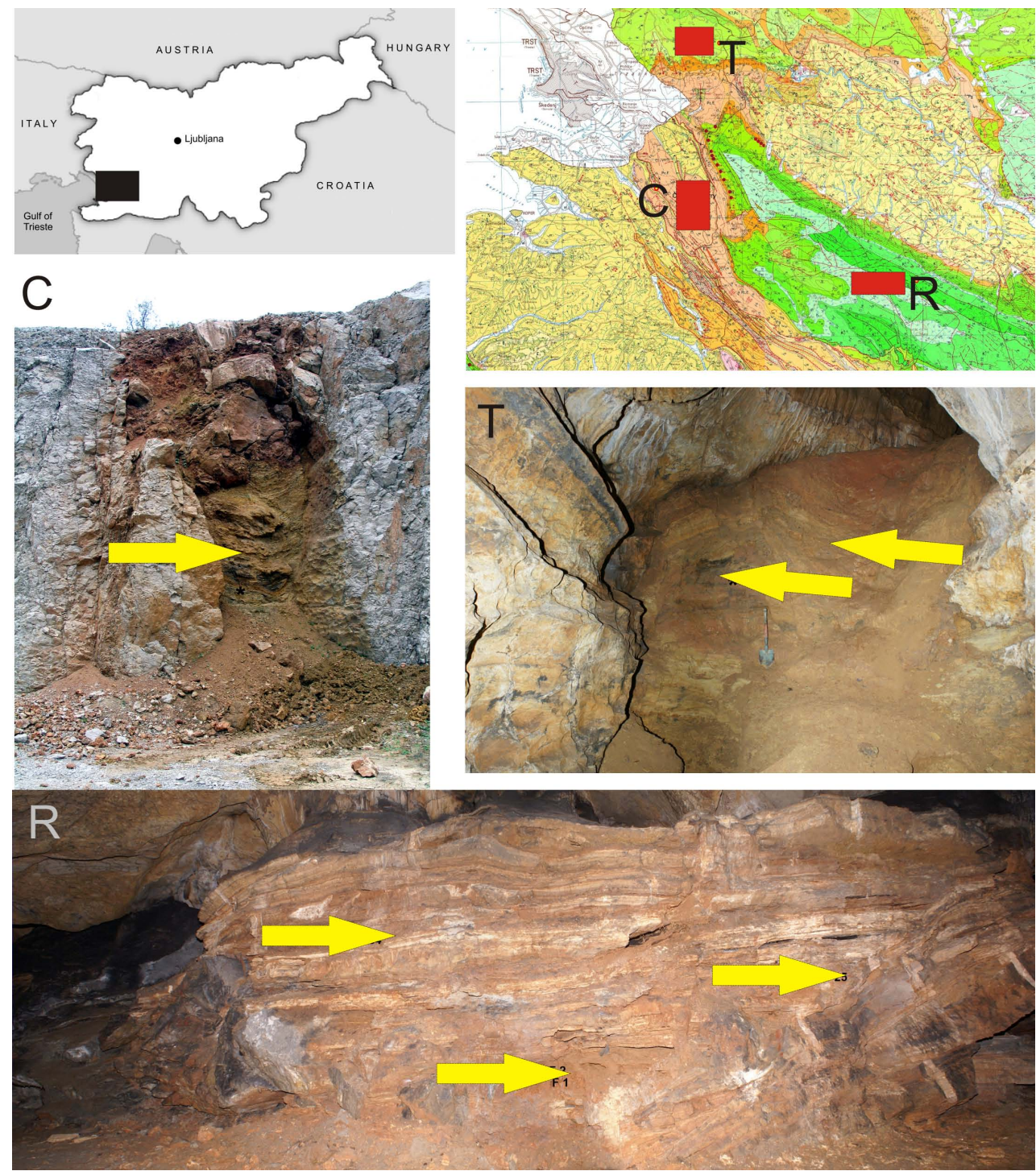

Fig. 1. Location of the studied sites in Slovenia (see the geological map in the upper right corner; map after Pleničar et al., 1969): C=fossil cave in the Črnotiče Quarry (the section is represented by an unroofed cave filled with yellow fluvial sediment covered by red clay with flowstone), $\mathrm{T}=$ Trhlovca Cave (the oldest part of the section with fluvial sediments), $\mathrm{R}=$ Račiška pečina Cave (the section is an alternation of flowstone and clay deposits; Photos by A. Mihevc).

\section{Materials and methods}

\subsection{The studied sites}

Three relic caves, all located in the Dinaric Classical Karst, were selected for this study - Trhlovca, Račiška pečina, and a cave in Črnotiče Quarry (Fig. 1) - also due to the fact that detailed paleomagnetic dating was calibrated by micromammal biostratigraphy in two of them (Horáček et al., 2007).

Trhlovca Cave $\left(45^{\circ} 40^{\prime} 18.8^{\prime \prime} \mathrm{N}\right.$; $\left.13^{\circ} 56^{\prime} 45^{\prime \prime} \mathrm{E}\right)$ belongs to the Divaška Cave System. The cave is part of an ancient and more extensive system completely choked by sediments. The cave was later partly rejuvenated and sediments exhumed as a consequence of the evolution of the underlying Divaška Cave
(Bosák et al., 1998, 2000). The preserved fluvial sediments and speleothems, deposited in vadose conditions, are located in stratigraphically relevant position (Fig. 2b). A vertical section, $4.5 \mathrm{~m}$ in thickness, was described in detail by Zupan Hajna et al. (2008b). Its central part is well stratified and starts from the top with a brownish-red, clayey sand with intercalations of light-greyish and yellowish-brown sands. The rest of the section is represented by multi-colored clays in the upper half and chocolate-brown clays below. In the basal interval, silty to very fine-grained sandy admixtures occur in bands and laminae. The arrangement of $\mathrm{R}$ (reverse) and $\mathrm{N}$ (normal) polarized magnetozones shows ages older than $1.77 \mathrm{Ma}$ (Zupan Hajna et al., 2008b). 
Table 1. A list of invertebrate fossils in the samples of cave sediments in Slovenia (only samples with identifiable animal remains are shown).

\begin{tabular}{|c|c|c|c|c|c|}
\hline & Site/Sample & $\begin{array}{l}\text { Short description } \\
\text { of the sediment }\end{array}$ & Identified taxa & $\begin{array}{l}\text { No. } \\
\text { individuals }\end{array}$ & Observation \\
\hline 1 & Trhlovca 1 (T1) & red clay & Miracarus n. sp. & 1 & new species \\
\hline 2 & Trhlovca 2 (T2) & beige clay & $\begin{array}{l}\text { Opiella (cf. Rhinoppia) n. sp. } 1 \\
\text { Dissorhina } \text { n. sp. }\end{array}$ & $\begin{array}{l}1 \\
1\end{array}$ & $\begin{array}{l}\text { new species } \\
\text { specimen in } \\
\text { poor condition }\end{array}$ \\
\hline 3 & Trhlovca 5 (T5) & red clay & $\begin{array}{l}\text { Daphnia sp. } \\
\text { Dissorhina } \mathrm{n} . \mathrm{sp} . \\
\text { Zygoribatula frisiae } \\
\text { Tetramorium sp. } \\
\text { Insecta larvae }\end{array}$ & $\begin{array}{l}1 \\
1 \\
1 \\
1 \\
1\end{array}$ & $\begin{array}{l}\text { new species } \\
\text { cosmopolite } \\
\text { cosmopolite } \\
\text { unidentified }\end{array}$ \\
\hline 4 & Račiška 4 (R4) & red clay & $\begin{array}{l}\text { Oppiella (Rhinoppia) n. sp. } 2 \\
\text { Miracarus } \mathrm{n} . \mathrm{sp} . \\
\text { Suctobelbella sp. ? }\end{array}$ & $\begin{array}{l}4 \\
2 \\
1\end{array}$ & $\begin{array}{l}\text { new species } \\
\text { new species } \\
\text { specimen in } \\
\text { poor condition }\end{array}$ \\
\hline 5 & Črnotiče 1 (C1) & yellow clay & $\begin{array}{l}\text { Orthocladiinae } \\
\text { Astigmatida? }\end{array}$ & $\begin{array}{l}1 \\
1\end{array}$ & $\begin{array}{l}\text { incomplete } \\
\text { specimen in } \\
\text { poor condition }\end{array}$ \\
\hline
\end{tabular}

Račiška pečina Cave $\left(45^{\circ} 30^{\prime} 12.5^{\prime \prime} \mathrm{N} ; 14^{\circ} 9^{\prime} 1.56^{\prime \prime} \mathrm{E}\right)$ represents a relic of an old cave system. The $2 \mathrm{~m}$ thick vertical section has a composite stratigraphic thickness of $6.5 \mathrm{~m}$ (Horáček et al., 2007; Zupan Hajna et al., 2008b; Fig. 2c). Its lower part consists of a vaulted stalagmite that includes several interbedded layers of red clays. It is overlain by a thick interval of red clays with some silty and sandy intercalations and thin calcite crusts and fossils (vertebrates and invertebrate-Potamon). The micromammals (with Apodemus, cf. Borsodia) belong to middle to late Mammal Neogene biozone 17 (MN17; ca. 1.8-2.4 Ma; Horáček et al., 2007; position of R1 and R2 in Fig. 2). The clays are ponded and partly covered by several collapse boulders. The upper part of the section consists of subhorizontally laminated, porous and light-colored flowstone with some ancient rimstone dams and interbedded red clays and silts. Lutitic interbeds between the flowstone layers resulted from successive flooding that deposited well-sorted fine-grained allochthonous sediments. This may indicate either a distant position far from the ponor of the surface river or an allogenic stream passing through a system of sumps (Horáček et al., 2007). The top of the section is flowstone with intercalations of brown cave loams with bone fragments of Ursus spelaeus. Fauna from the clay permitted the arrangement of the interpreted magnetozones with the Geomagnetic Polarity Time Scale (GPTS; Cande and Kent, 1995). The boundary of N- and R-polarized magnetozone within the interval with fauna was identified with the bottom of the C2n Olduvai subchron (1.770-1.950 Ma). The basal sediments can be correlated with the lower part of the Matuyama chron (2.150-2.581 Ma) and the Gauss chron (2.581-3.580 Ma) (Horáček et al., 2007).
Quarry operations in the Črnotiče Quarry $\left(45^{\circ} 33^{\prime} 56.3^{\prime \prime} \mathrm{N}\right.$; $13^{\circ} 52^{\prime} 47.7^{\prime \prime}$ E) uncovered many caves completely filled with sediments (Bosák et al., 1999, 2004; Mihevc, 2001, 2007; Fig. 2a). The studied section is located in the western quarry wall and represents a relic of an extensive, sediment-filled passage with a diameter of about $10 \mathrm{~m}$ and a height of more than $17 \mathrm{~m}$. Its top is filled by speleothem breccia with red clay matrix. This is underlain by an interval, up to 4.5 thick, of light-colored, laminated silts and clays, sometimes sandy, overlying the rest of the section with deep erosion and a slight unconformity inside. The lowermost $7 \mathrm{~m}$ of the cave fill are composed of cyclically/rhythmically arranged multi-colored fluvial sediments (clays to intraclastic microconglomerates). This fill rests on sessile tubes of the serpulid Marifugia cavatica on the northern cave wall (Mihevc, 2000; Mihevc et al., 2001). The mammal remains (with Deinsdorfia sp., Beremedia fissidens, Apodemus cf. atavus, Rhagapodemus cf. frequens, Glirulus sp., Cseria sp.) that belong to MN15-MN16 (ca. 3.0-4.1 Ma) were found in the same horizon as the serpulids (Horáček et al., 2007). The basal $1 \mathrm{~m}$ is composed of multi-colored laminated silts and clays developed in two sequences separated by an angular unconformity. The fauna indicated an age of the fill older than $1.77 \mathrm{Ma}$ (base of the C2n Olduvai subchron). Most probably, the fill belongs to the Gauss chron (2.6-3.6 Ma) or the other N-polarized subchron within the Gilbert chron (4.18-4.29 or 4.48-4.62 Ma; Bosák et al., 2004; Horáček et al., 2007). 

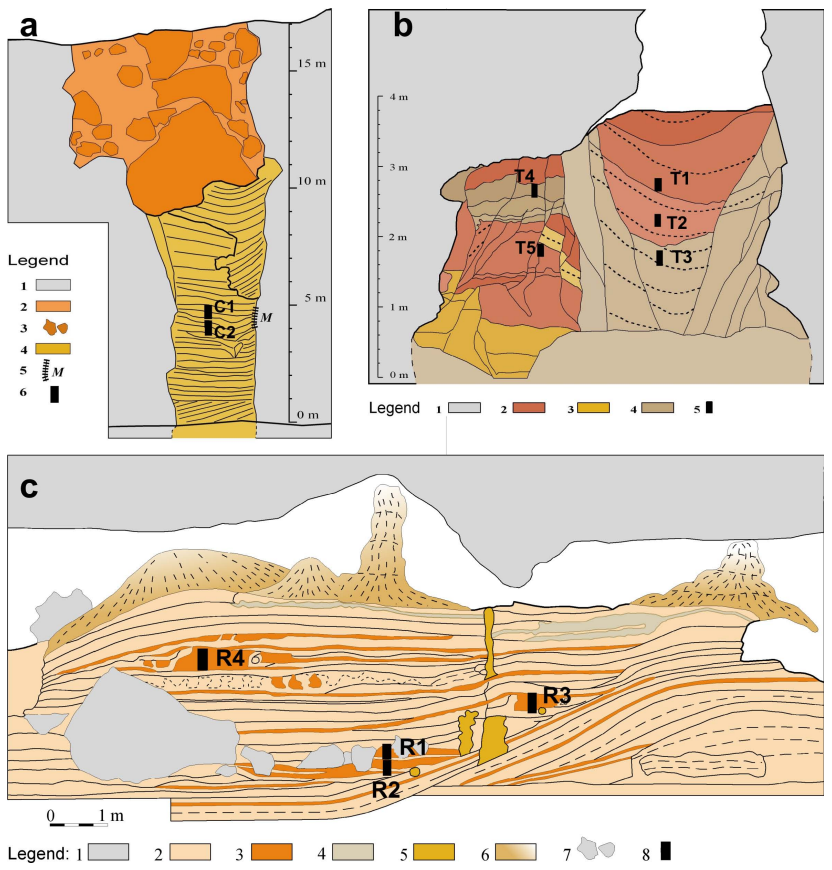

Fig. 2. Lithological sections at the studied sites: (a) a section in the filled horizontal cave passage cut by the Črnotiče Quarry (the original section): 1 =limestone, 2 =flowstone mixed with reddish clay, $3=$ large flowstone boulders, $4=$ allogenic laminated fluvial sediment, $5=$ wall and sediment with tubes of Marifugia $\mathrm{ca}$ vatica, $6=$ sampling points $(\mathrm{C} 1-\mathrm{C} 2$; modified from Bosák et al., 2004). (b) A section exposed in the Trhlovca Cave, several meters in thickness: $1=$ limestone, $2=$ reddish younger fill of clay, silt and fine sand, $3=$ clays lighter in color, with a higher sand proportion, 3 =yellowish brown sandy clay, $4=$ brownish to ochre sandy clay, 5 = sampling points (T1-T5; modified from Bosák et al., 2006); (c) Račiška pečina Cave section: $1=$ limestone 2 = flowstone, $3=$ red clay, silt and sand, $4=$ brown clays with gravel and cave bear bones, $5=$ stalagmites in flowstone, $6=$ speleothems on the section surface, $7=$ collapsed limestone blocks, $8=$ sampling points (R1R4; modified from Zupan Hajna et al., 2008b).

\subsection{Sampling protocols and invertebrate fossil identification}

A total of 11 samples were taken from the selected sites as indicated in Fig. 2. The samples were taken from the exposed faces, which had already been sampled for paleomagnetic and paleontological studies. Given the exploratory nature of our research, the samples were selected from what appeared to be distinct, stratigraphic units, located in positions that would allow a clear correlation with the previously established paleontological and magnetic chronostratigraphy. In the Črnotiče Quarry, samples were taken only from the upper part of the originally described section that remained intact after a recent collapse of the topmost sediments in the quarry face.

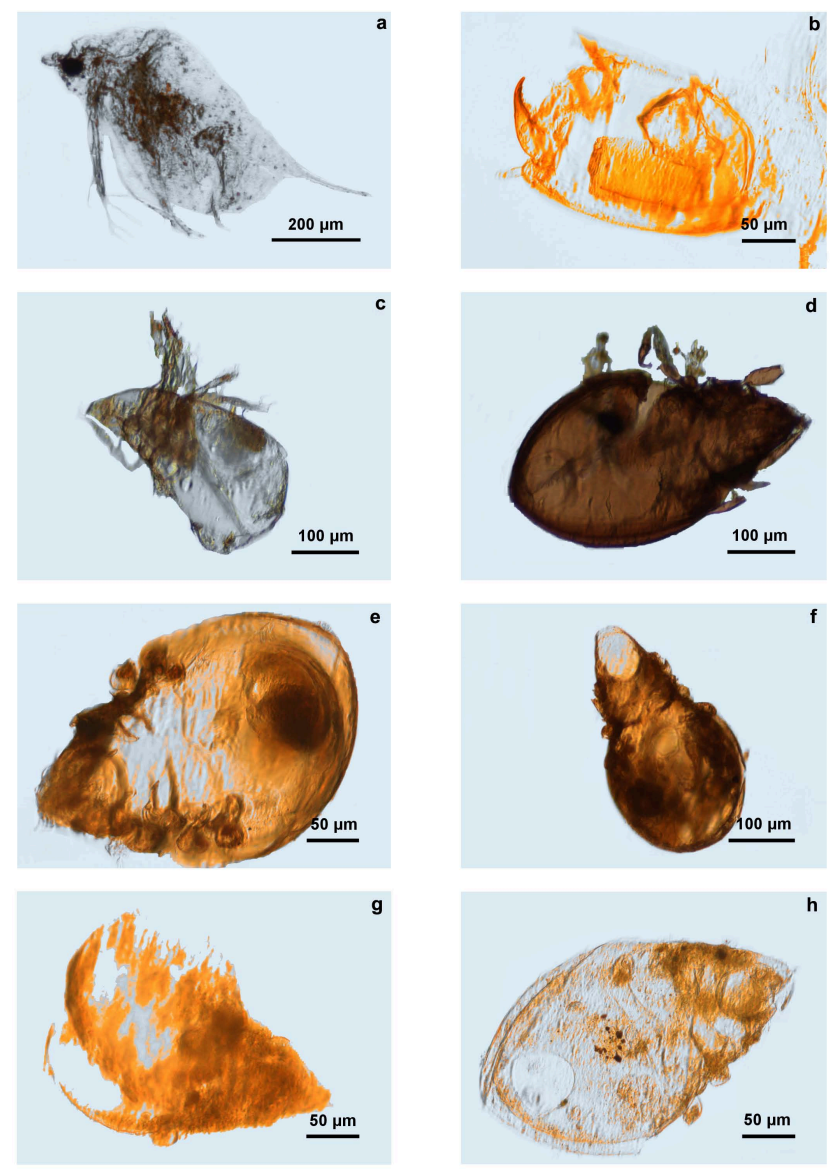

Fig. 3. Light microscope photographs of the identified fossil invertebrates in the cave sediments in Slovenia: (a) Daphnia sp.; (b) Orthocladiinae; (c) Dissorhina n. sp.; (d) Zygoribatula frisiate; (e) Miracarus n. sp.; (f) Opiella (cf. Rhinoppia) n. sp. 1; (g) Suctobelbella sp. ?; (h) Oppiella (Rhinoppia) n. sp. 2.

Approximately $1 \mathrm{~kg}$ of sediment was taken from each sampling point and placed in sealed plastic bags with a label. In the laboratory, the samples were kept in $10 \% \mathrm{KOH}$ for $30 \mathrm{~min}$, and washed successively through sieves of $250 \mu \mathrm{m}$, $125 \mu \mathrm{m}$ and $40 \mu \mathrm{m}$. Sub-samples for each sieve dimension were examined separately under an Olympus SZX2 stereomicroscope in $90^{\circ}$ alcohol and each specimen was identified under an Olympus BX51 microscope. Identification of the individuals was carried out following the specific methods for each group.

\section{Results and discussion}

The number of identifiable invertebrate fossils in all samples was very low (Table 1). Some of the samples were completely invertebrate-sterile. Unidentifiable animal fragments and vegetal fragments were also found. The only relatively well-preserved specimens belong to the groups of Cladocera 
(Crustacea), Oribatida (Acarina), and Chironomida and Hymenoptera (Insecta). All these groups are commonly identified in invertebrate fossil assemblages from lake sediments (Elias, 2007).

\subsection{Faunal inventory}

\subsubsection{Crustacea Cladocera}

One Daphnia sp. was identified in the Trhlovca Cave. The identified specimen is in a relatively good condition (Fig. 3a), but completely flattened laterally. Daphnia are known as large-bodied pelagic offshore cladocerans. Korhola (1999) and Korhola et al. (2000) found maximum lake depth to be the most important factor explaining cladoceran distribution in Fennoscandian lakes. Jeppesen et al. (2001) found only post-abdominal claws, mandibles and ephippia of Daphnia species in deep Quaternary lake sediments.

\subsubsection{Acarina Oribatida}

Mites of the suborder Oribatida (Acarina, Arachnida) are typical soil-dwelling microarthropods, which can be also found in caves. Mites are of high potential value as bioindicators of the ecological conditions in terrestrial and aquatic ecosystems (Lebrun and van Straalen, 1995; Behan-Pelletier, 1999; Gulvik, 2007; Gergócs and Hufnagel, 2009). Almost all studies support the idea of a group with many representatives living in humid habitats. Drought susceptibility exerts its effects via food limitation indirectly by a decrease of microbiota in soil or other substratum as a result of lack of water. Nevertheless, some species adapted also to xeric conditions or high values of humidity. These minute arthropods are usually preserved well enough in lacustrine or fluvial sediments and in sufficient numbers to be useful as proxies in investigations of Quaternary paleoclimate, paleoecology and stratigraphy (Solhøy and Solhøy, 2000; Solhøy, 2001; Polyak et al., 2001). Five species were identified in the studied samples and four of them are new to science.

A new species belonging to Miracarus (Microzetidae) (Fig. 3e) was found in the sediments of the Trhlovca and Račiška caves. Modern representatives of the genus are forest-litter inhabitants. Oppiella (Rhinoppia) sp. 1 and $O p$ piella (Rhinoppia) sp. 2 (Fig. 3f, h), two species of the family Oppidae were identified in the sediments of the Trhlovca and Račiška caves. Species of the genus Opiella (sensu lato) can be considered one of the most common arthropod groups on Earth (Norton and Palmer, 1991) with high diversity and abundance in forest litter, also present in shrublands, ecotone zones and grasslands. The new species of Oppiella from the Račiška cave morphologically resembles a species known from modern cave environments. The difference is in the length of sensilla, being much shorter than in the extant form. The species is therefore an extinct element of the cave fauna of Slovenia. Dissorhina sp. (Fig. 3c) of the same family (Opiidae) was represented in the Trhlovca Cave by two specimens, probably belonging to the same, new species. Some species of this genus prefer the border between forest and open areas (Seniczak et al., 2006). Taylor and Wolters (2005) mentioned the tolerance of this genus to drought. Zygoribatula frisiae (Oribatulidae) (Fig. 3d) found in the Trhlovca Cave is a species, found today in more arid settings (Shepherd et al., 2002). The species is xero-tolerant, today known from repeatedly drying-out mosses and lichens, often in arboricol microhabitats. Suctobelbella sp. (Suctobelbidae) (Fig. 3g) of the Trhlovca Cave resembles species of the recent genus Suctobelbella in some characters but displays some specific characters, which may define a different genus. Species of this family are common in litter and upper organic layer of forest soils, especially with a large amount of decomposing organic matter and with abundant fungal hyphae. Some of the living species have been found in rotting wood and under bark of dead trees.

\subsubsection{Insecta Chironomida}

One representative of Orthocladiinae (Fig. 3b) was identified in the Črnotiče Quarry cave fill. The absence of mentum made the identification of the lower taxon impossible. Subfamily Orthocladiinae is a group of chironomid Diptera whose larvae prefer lotic habitats with cold and welloxygenated waters (Dimitriadis and Cranston, 2001; Walker, 2007). Representatives of this family inhabit cold and running streams or unstable sandy bottoms of lakes, but are generally adapted to low food (Walker, 2007) and are intolerant to low oxygen levels (Eggermont et al., 2008). This is a widely distributed family of chironomids and its representatives are frequently found in lake sediments.

\subsubsection{Insecta Hymenoptera}

One individual of the genus Tetramorium was found in the sediments of the Trhlovca Cave. The genus is a typical inhabitant of dry landscapes with shrubs. The individual lacks the head, but is otherwise well preserved. It represents a genus with very large distribution in the present fauna.

\subsection{Paleoenvironmental significance of the fossil invertebrates}

Five taxa identified are new to science and their description is in progress. Only a single taxon as yet identified at a species level is found in the modern fauna (Zygoribatula frisiae). Two taxa were identified at a genus level (Daphnia and Tetramorium) and one taxon as subfamily (Orthocladiinae), due to their poor conservation. The cave richest in fossils was Trhlovca Cave with six identified taxa in three of the five samples. The maximum number of taxa belongs to the oldest sample (T5), presumably due to climatic conditions and sedimentation processes at the time of deposition and subsequently. 


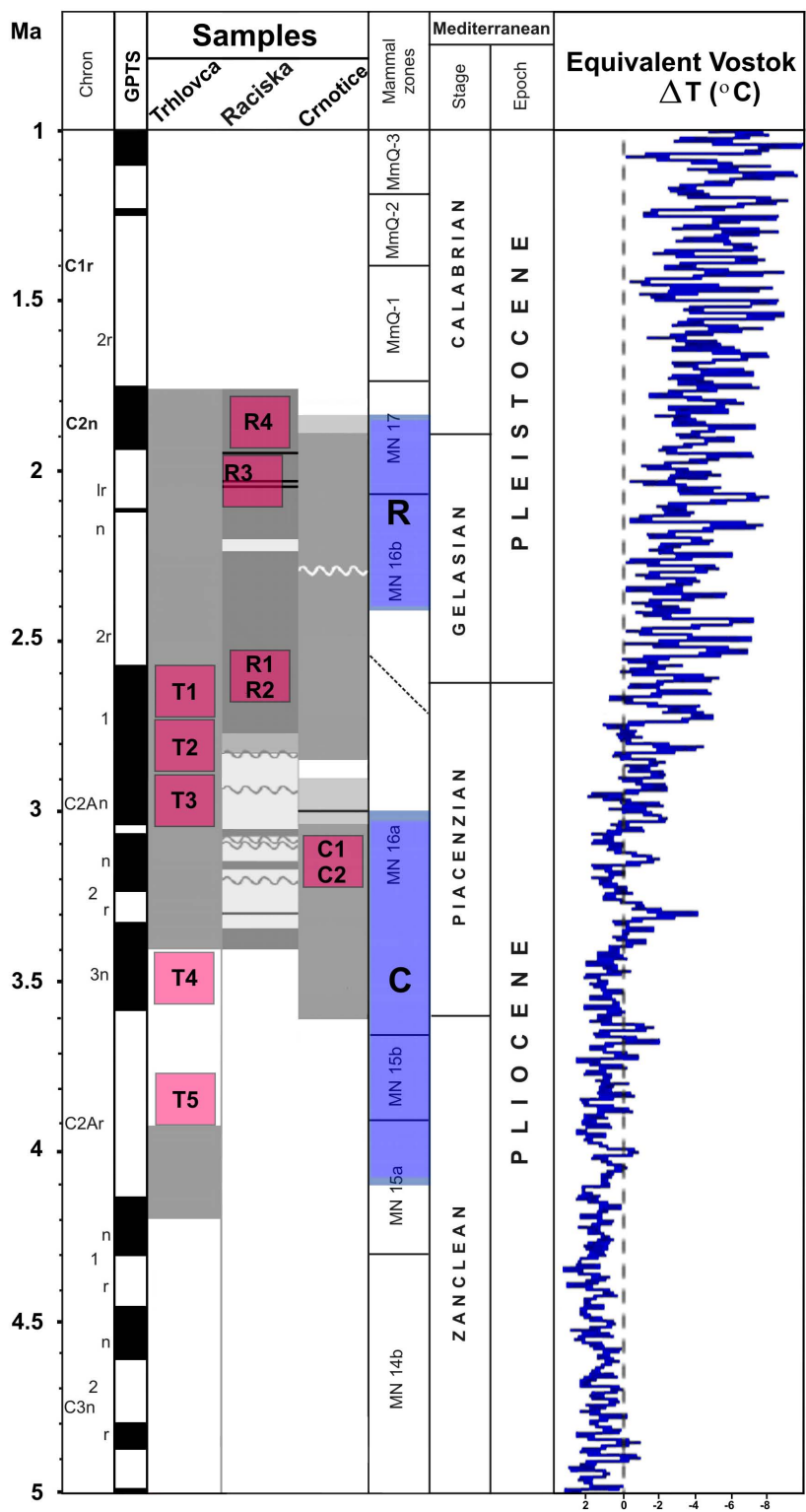

Fig. 4. A correlation of the obtained magnetostratigraphic results with the standard paleomagnetic scale (GPTS; after Cande and Kent, 1995; modified after Horáček et al., 2007), mammal zones, temperature estimates (after Lisiecki and Raymo, 2005) and position of the samples with invertebrates (in red) and vertebrates (in blue): $\mathrm{T}=$ Trhlovca Cave, $\mathrm{R}=$ Račiška Cave, $\mathrm{C}=$ fossil cave in the Črnotiče Quarry.

All the analyzed samples were taken from cave sediments deposited during the Pliocene and Pleistocene periods, as dated by magnetostratigraphy and paleontological content (Fig. 4). During the Pliocene, the climate is globally known to have become cooler and drier than during the Miocene (Robinson et al., 2008), followed by the more pronounced Pleistocene cooling. Broadly, two climatic stages are defined in the period covered by the deposition of clastic sediments in the sampled caves (Fig. 5): the Early - Middle Pliocene (ca. 5.3 Ma to 3.6 Ma) with higher temperatures, and the Late Pliocene - Early Pleistocene (ca. 3.6 to $1.77 \mathrm{Ma}$ ) with lower temperatures, more similar to the present-day climate (Haywood, 2009).

Most of the invertebrate fossils were found in the Trhlovca Cave. Samples 1-3 belong to a more recent period than the older infilling where samples 4-5 were collected, but all the studied samples are older than 1.77 Ma (Zupan Hajna et al., 2008b, 2010). Clay samples T1 and T2 include taxa that are typical for forest habitats with relatively high amounts of dead organic matter in the upper horizon of soil (Miracarus and Oppiella) or taxa which can be found in the ecotone zones or in open, moderately humid areas (Dissorhina). From the oldest samples, T4-T5, only T5 contained fossil remains. The ecotone zone - typical Dissorhina was found in association with dry habitat taxa, such as Zygoribatula and Tetramorium. Fossils from these three samples indicate a transition from a warmer period with relatively drier vegetation (Early or Middle Pliocene) to a more humid and forested habitats of the Late Pliocene/Early Pleistocene. The presence of Daphnia sp. in sample T5 suggests the presence of a lake or a low hydraulic regime of the stream, as well as the proximity of cave entrance. This assumption is also supported by the varved sediments that indicate continuous deposition in the past, during single-flood events or flood pulses that probably lasted less than a few thousand years (Zupan Hajna et al., 2008a). The relatively good preservation of this cladoceran is also indicative of a slow flow from the surface down to place of deposition, possibly due to the still epiphreatic position of some parts of the subterranean system (Mihevc, 2007) and to the short-distance transport. The presence of Daphnia species, as an indicator of oligotrophic (low food) environments (Szeroczyńska and Zawisza, 2005), supports the hypothesis of a drier vegetation on the surface.

Only sample R4 provided fossil invertebrates in Račiška pečina. These are represented by three individuals of oribatid mites belonging to the same ecological group of forest inhabitants. Sample R4 comes from the upper half of the section of this cave that belongs to the Early Pleistocene (termination of the Olduvai-chron).

The only chironomid identified at a family level was found in sample C1 in Črnotiče Quarry. Located in the upper half of the sediment section, the Orthocladiinae dipteran can be used as an indicator for colder and well-oxygenated waters. The individual was carried underground by a relatively fast flowing river, which suggests a colder climate with more intense precipitation towards the end of the Pliocene.

\subsection{Correlations with other proxies}

The discovery of five new species (and perhaps a new genus) is important not only for the taxonomy of the group of mites (in this case), but is also of paleoenvironmental significance. The Pliocene/Pleistocene cave sediments show 


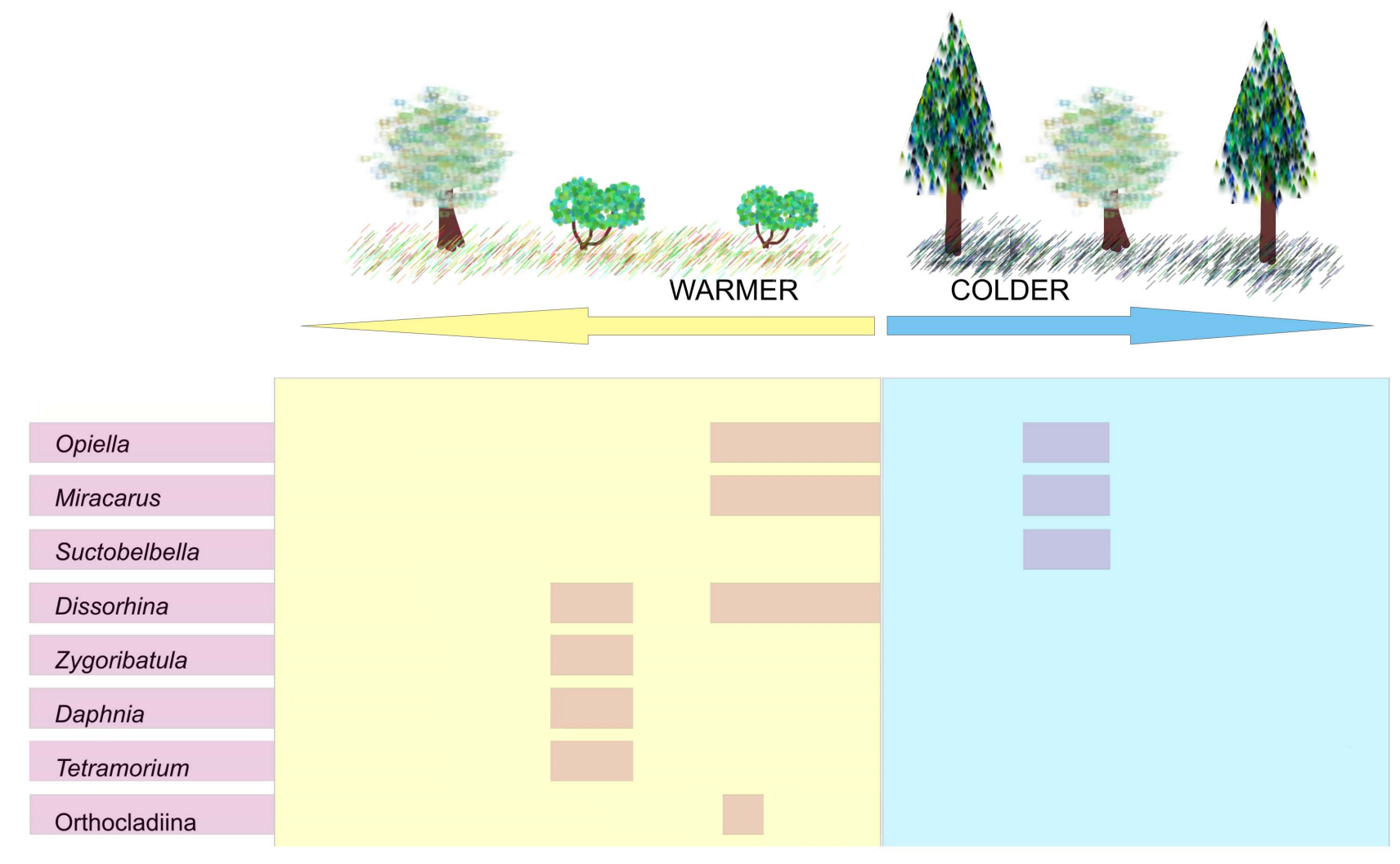

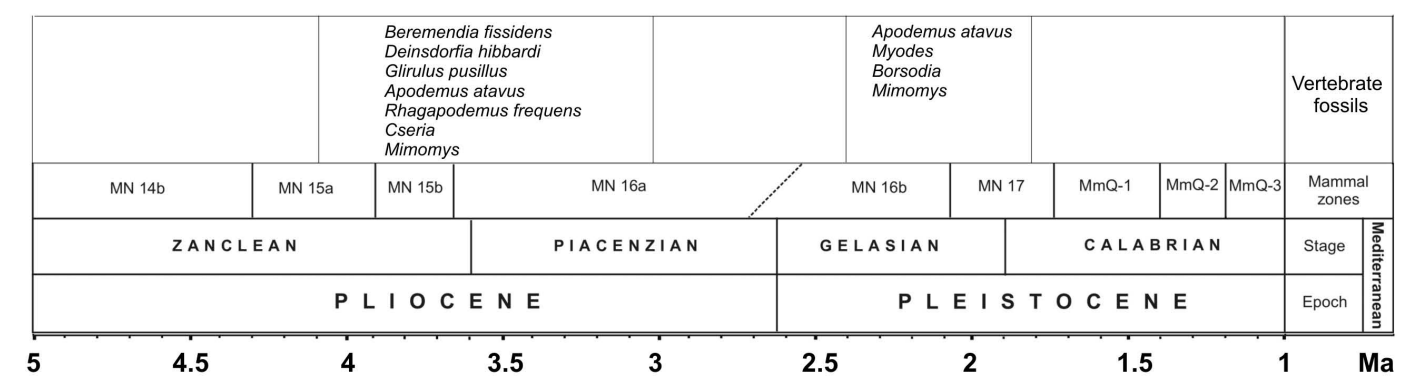

Fig. 5. Invertebrate fossils found in the studied caves, correlated with climate, vegetation and fossil vertebrates.

a very low concentration of taxa, or none at all in more than half of the analyzed samples. The scarcity of fauna remains makes further biostratigraphic interpretation impossible, but the presence and ecology of some taxa can be correlated with the discovered vertebrate remains as well as with the climate and corresponding vegetation of the different Pliocene/Pleistocene periods, indicating a transition from a dry or mild climate with mixed forest to a colder climate and more humid forest (Table 2, Fig. 5). The use of less frequently occurring zoological remains in paleolimnology was emphasized by Luoto (2009) as an important proxy for environmental changes.

The fossil vertebrate assemblage from the Črnotiče Quarry, including Deinsdorfia sp., Beremendia fissidens, Apodemus cf. atavus, Rhagapodemus cf. frequens, Gliru- lus sp. and Cseria sp. (Horáček et al., 2007), is typical for a temperate and humid climate. The high number of forest and shrub inhabitants (Apodemus, Glirulus, Myodes genera), together with taxa that are widely distributed in temperate and humid climates (Beremendia fissidens, Blarinoides and Deinsdorfia genera), is indicative of a mild climate. At Račiška pečina Cave, the most important difference is the presence of Myodes and Borsodia (Horáček et al., 2007) as indicators of a colder and drier climate. Owing to the scarce presence of identifiable invertebrates, a correlation with the equally scarce vertebrate record is problematic. Only three of the invertebrate samples ( $\mathrm{C} 1, \mathrm{~T} 1$ and $\mathrm{R} 4)$ come from the same periods as the found vertebrate fossils, and correlations were made only for these samples. Sample C1 provides a single indicator for cold/well-oxygenated water 
Table 2. Taxa found in cave sediments of Slovenia with the corresponding vegetation, sediment type and origin, and vertebrate fossils.

\begin{tabular}{|c|c|c|c|c|c|c|}
\hline \multirow[t]{2}{*}{ Stage } & \multicolumn{3}{|c|}{ TAXA } & \multirow[t]{2}{*}{ Environment } & \multirow{2}{*}{$\begin{array}{l}\text { Sediment } \\
\text { origin }\end{array}$} & \multirow[t]{2}{*}{ Vertebrates } \\
\hline & Trhlovca & Račiška & Črnotiče & & & \\
\hline \multirow{3}{*}{$\begin{array}{l}\text { Upper } \\
\text { Pliocene/ } \\
\text { Lower } \\
\text { Pleistocene }\end{array}$} & $\begin{array}{l}\text { Miracarus } \\
\text { Opiella Dissorhina }\end{array}$ & - & - & $\begin{array}{l}\text { forest, } \\
\text { ecotone zones }\end{array}$ & $\begin{array}{l}\text { surface, } \\
\text { fluvial }\end{array}$ & - \\
\hline & - & $\begin{array}{l}\text { Oppiella Miracarus } \\
\text { Suctobelbella } \\
\left(\text { Potamon }^{*}\right)\end{array}$ & - & $\begin{array}{l}\text { forest, } \\
\text { ecotone zones, } \\
\text { grasslands + river }\end{array}$ & $\begin{array}{l}\text { surface, } \\
\text { fluvial }\end{array}$ & $\begin{array}{l}(\text { fish teeth*), } \\
\text { micromammals } \\
\text { living in steppe } \\
\text { and tree habitats }\end{array}$ \\
\hline & - & - & $\begin{array}{l}\text { Orthocladiinae } \\
\text { (Marifugia cavatica*) }^{*}\end{array}$ & $\begin{array}{l}\text { cold, } \\
\text { well oxygenated } \\
\text { water }\end{array}$ & $\begin{array}{l}\text { surface, } \\
\text { fluvial }\end{array}$ & $\begin{array}{l}\text { (fish teeth*), } \\
\text { micromammals } \\
\text { living in tree } \\
\text { and riverside } \\
\text { habitats }\end{array}$ \\
\hline $\begin{array}{l}\text { Lower } \\
\text { Pliocene }\end{array}$ & $\begin{array}{l}\text { Daphnia, } \\
\text { Dissorhina, } \\
\text { Zygoribatula } \\
\text { Tetramolium }\end{array}$ & - & - & $\begin{array}{l}\text { dry landscape with } \\
\text { shrubs + river }\end{array}$ & $\begin{array}{l}\text { surface, } \\
\text { fluvial }\end{array}$ & - \\
\hline
\end{tabular}

* Mentioned in Horáček et al. (2007).

(Orthocladiinae), which is supported by the presence of Beremendia, Rhagapodemus typical for temperate climate, and of Cseria and Mimomys that are water-related micro-mammals. Samples T1 and R4 include Oribatida invertebrates (genera Oppiella, Miracarus and Suctobelbella) that inhabit forest litter, shrublands, ecotone zones and grasslands, and vertebrates which indicate the presence of trees in wet forests and steppic habitats, typical habitats for Myodes and Borsodia. The presence of invertebrate drought-tolerant taxa in T5 indicates a landscape with shrubs and grassland during the late Early Pliocene. The presence of forest inhabitants in $\mathrm{T} 1$ and R4 correlated with the presence of cold/dry-associated vertebrates points to a colder climate during the Mid-Pleistocene. Between these two chronologically extreme samples, invertebrates were also identified in samples $\mathrm{C} 1$ and T2. Sample $\mathrm{C} 1$ corresponds to the advent of the Late Pliocene cooling and probably higher flow rates on the surface, which explains the presence of the chironomid. Sample T2 fits within the picture of forests mixed with open areas during the Early Pleistocene.

No pollen was found in the studied samples and sections, but detailed studies on the nearby Italian and periMediterranean sites given in Bertini (2010) can be well correlated with the invertebrate fossils found in the Slovenian cave sediments (Table 2). During the Zanclean, the climate was warmer and drier or more humid than today, depending on the geographical latitude and altitude (Faquette et al., 2006); forest taxa of humid subtropical to warm temperate zones were dominant (Bertini, 2010). The gen- eral decrease of humidity and installation of drier conditions during the Piacenzian occurred prior to $2.5 \mathrm{Ma}$ (Bertoldi et al., 1989). Alternations of forest vegetation and steppes, with typical open vegetation phases characterized the following early Pleistocene, during the Gelasian and the Calabrian (Bertini, 2010). In general, the floral composition and structure of vegetation of the Pliocene-Pleistocene are characterized by the rare appearance of new species and by spatially asynchronous events of disappearance of the same taxon (Bertini, 2010). Frequent changes in both climate and vegetation can explain the extinction of some of the identified invertebrate taxa in the cave sediments of Slovenia. In general, faunal changes depend on the environment, defined mostly by climate and vegetal associations. If changes are frequent and of relatively short duration, some of the taxa that are unable to adapt may get extinct, or evolve into different species. Oribatida is a group with a lower mobility than flying invertebrate species, and their migration can only be over short distances, following the slowly migrating vegetation or vegetal associations. The identified new Oribatida species can be considered either members of an extinct faunal group with no relatives in the present fauna of southern Slovenia, or ancestors of a living species which have undergone evolution in the present-day habitats or in different areas nearby. Vegetation succession in time contributed to the settlement of a complex mosaic of different climates/biomes in the Mediterranean zone (Bertini, 2010). This situation documented for flora is supported by the invertebrates found in the cave sediments. The section that provided most of the specimens, 
in the Trhlovca Cave, yielded taxa indicative of mixtures of forests with open dry areas. As already documented by Finlayson et al. (2008) for more recent sediments, environmental changes must be taken into account at small or medium scales. Invertebrate fossils can provide information at small scales and must be associated with other proxies and preferably with more sites of the same region in order to provide paleoenvironmental information that would be significant at regional scale.

\subsection{Implications for the reconstruction of karst evolution}

If the standing condition of the fossil is known, its endpoint can be used to infer some of the geological processes that acted on the body during its transport to the site of deposition (Erickson, 1988). The presence of surface animals in pre-Quaternary interior facies of cave sediments is indicative for an intense karst evolution of the Dinaric karst, including the filling of a part of the cavities with sediment during the Neogene. The very low abundance of fossils deposited in clastic cave sediments of the interior facies is well known (e.g., Horáček and Ložek, 1988). This is probably related to the runoff in the drainage area or to the hydraulics of the subterranean streams. Almost all of the studied invertebrate samples have at least one aquatic component, and all (with a single possible exception) are surface invertebrates, which were brought inside the caves by allogenic streams and deposited together with the sediments. The most common clastic sediments in the studied caves are different types of fine laminated clays and silts. They were deposited from floodwater suspended load under conditions of pulsed flow or cave lakes comparable with slackwater facies of Bosch and White (2004). This depositional process corresponds to more or less regular flooding of karst areas by sinking rivers. Mineral assemblages of the cave deposits were derived from highly homogenized weathering products of Eocene flysch sediments and soil cover on Paleocene and Cretaceous limestones (Zupan Hajna et al., 2008b). The tectonically-driven lowering of the regional base level was connected with the change in tectonic regime at ca. $6 \mathrm{Ma}$ (Vrabec and Fodor, 2006). This caused a transition from an epiphreatic to a vadose regime, followed by a decrease in hydraulic head in some cave systems or their higher-situated parts and a complete fill with fluvial sediments as a consequence (Mihevc, 2007; Zupan Hajna et al., 2008b).

As already mentioned, the presence of Daphnia sp. and its relatively good preservation in sample T5 indicates the existence of a system with low hydraulic head at the cave entrance and multiple flood events that contributed to the continuous deposition of varved and/or cyclically arranged sediments. The chironomid in sample $\mathrm{C} 1$ indicates a period of relatively high flow rate in a vadose regime. The chironomid was found at the same level as Marifugia cavatica, serpulid polychaetes attached to walls at the air/karst-water interface, still living in the caves of the Dinaric karst (for summary see Mihevc et al., 2001).

Pre-Quaternary arthropod remains, abundant in marine settings and quite common in amber, are rare and have yet been reported in continental sediments only from Arctic environments (see a complete list in Elias, 2010). The depositional mechanisms and the low intensity of biochemical processes can explain the relatively good state of preservation of old invertebrate remains both in the cave sediments and Arctic lake sediments. Although the number of identified invertebrates at the studied Slovenian sites is small, their state of preservation is relatively good considering the age of the sediments. This may suggests a combination of: (1) a relatively short and slow transport to the site of deposition, (2) a rapid burial, i.e., a high sedimentation rate, and (3) subdued microbial and biochemical processes that could have altered the entire organisms.

\section{Conclusions}

Three sites of relic caves from the Classical Karst of Slovenia provide first evidence of Pliocene/Pleistocene invertebrate remains in continental clastic sediments from interior cave facies in temperate regions. These finds suggest that cave sediments can preserve yet another proxy for the assessment of paleoclimatic and paleoenvironmental conditions. This new proxy may be important for a number of reasons: (i) the scarcity of vertebrate fossils in pre-Quaternary cave deposits; (ii) the need for cross-validation of inferred paleoenvironmental settings in the case of incomplete or ambiguous coeval proxies; (iii) the cave conditions that are prone to a better preservation of old chitinous invertebrates when compared to surface settings; (iv) its added-value as a source of information on speleogenesis and evolution of karst hydraulic regimes even for paleokarst settings.

Caves are known as systems with low-energy input from the surface and low-energy in situ production. This may hamper the use of fossil invertebrates from caves due to the relatively low chance of finding identifiable cave or surface specimens transported into caves. However, for the three described sites, a relatively low number of invertebrate specimens were successfully identified and dated by biostratigraphy-calibrated magnetostratigraphy back to ca. 1.77 to ca. $4.8 \mathrm{Ma}$, i.e., across the Pliocene/Pleistocene boundary. When cross-correlated with the coeval vertebrate fauna, these findings support the idea of a colder phase associated with the Pliocene/Pleistocene transition, while also bringing new insights on the regional karst evolution.

Acknowledgements. The authors are grateful to Ilse Bartsch, Karina Battes, Steve Brook, Mirela Cîmpean, Bálint Marko, Laura Momeu for the help with taxa recognition and ecological information. Jiři Adamovič has kindly helped with the English revision of the manuscript. This study was funded through the 
KARSTHIVES Project PCCE_ID_31/2010 funded by CNCSISUEFISCDI (Romania; granted to SC), Grant Agency AS CR No. IAA300130701 (Paleomagnetic research of karst sediments: paleotectonic and geomorphological implications; granted to $\mathrm{PB}$ ) and the Institutional Research Plan No. AV0Z30130516 of the GLI AS CR, v. v. i. The authors thank to editor Wolfgang Kiessling and reviewers Ira Sasowski and John Holsinger for their insightful comments.

Edited by: W. Kiessling

\section{References}

Bastin, B.: L'analyse pollinique des stalagmites: une nouvelle possibilité d'approche des fluctuations climatiques du Quaternaire, Annals. Soc. Geol. Belgique, 102, 13-19, 1978.

Bastin, B., Cordy, J.-M., Gewelt, M., and Otte, M.: Fluctuations climatique enregistreés depui 250000 ans dans le couches de remplissage de la Grotte Scladina (Province de Namur, Belgique), Bull. Assoc. Franc. Etude Quatern., 1/2, 168-177, 1986.

Behan-Pelletier, V. M.: Oribatid mite biodiversity in agroecosystems: role for Bioindication, Agr. Ecosyst. Environ., 74, 411423, 1999.

Bertini, A.: Pliocene to Pleistocene palynoflora and vegetation in Italy: State of the art, Quatern. Int., 225, 5-24, 2010.

Bertoldi, R., Rio, D., and Thunell, R.: Pliocene-Pleistocene vegetational and climatic evolution of the south-central Mediterranean, Palaeogeogr. Palaeocl., 72, 263-275, 1989.

Bosák, P.: Karst processes from the beginning to the end: how can they be dated?, in: Evolution of Karst: From Prekarst to Cessation, edited by: Gabrovšek, F., Carsologica, Založba ZRC, Postojna-Ljubljana, 2002.

Bosák, P.: Karst processes and time, Geologos, 14, 15-24, 2008.

Bosák, P., Ford, D. C., Głazek, J., and Horáček, I. (Eds.): Paleokarst. A Systematic and Regional Review, Elsevier-Academia, Amsterdam-Praha, 1989.

Bosák, P., Pruner, P., and Zupan Hajna, N.: Paleomagnetic research of cave sediments in SW Slovenia, Acta Carsologica, 27, 151179, 1998.

Bosák, P., Mihevc, A., Pruner, P., Melka, K., Venhodová, D., and Langrová, A.: Cave fill in the Črnotiče Quarry, SW Slovenia: Palaeomagnetic, mineralogical and geochemical study, Acta Carsologica, 28, 15-39, 1999.

Bosák, P., Pruner, P., Mihevc, A., and Zupan Hajna, N.: Magnetostratigraphy and unconformities in cave sediments: case study from the Classical Karst, SW Slovenia, Geologos, 5, 13-30, 2000.

Bosák, P., Pruner, P., and Kadlec, J.: Magnetostratigraphy of cave sediments: application and limits, Stud. Geophys. Geod., 47, 301-330, 2003.

Bosák, P., Mihevc, A., and Pruner, P.: Geomorphological evolution of the Podgorski Karst, SW Slovenia: Contribution of magnetostratigraphic research of the Črnotiče II site with Marifugia sp., Acta Carsologica, 33, 175-204, 2004.

Bosch, R. F. and White, W. B.: Lithofacies and transport of clastic sediments in karstic aquifers, in: Studies of Cave Sediments. Physical and Chemical Records of Paleoclimate, edited by: Sasowsky, I. D. and Mylroie, J., Kluwer Academic/Plenum Publishers, New York, 2004.
Bottrell, S.: Organic carbon concentration profiles in recent cave sediments: Records of agricultural pollution or diagenesis?, Environ. Pollut., 91, 325-332, 1996.

Brinkman, R. and Reeder, P.: The relationship between surface soils and cave sediments: an example from west central Florida, USA, Cave Karst Sci., 22, 95-102, 1995.

Cande, S. C. and Kent, D. V.: Revised calibration of the geomagnetic polarity timescale for the Late Cretaceous and Cenozoic, J. Geophys. Res., 100, 6093-6095, 1995.

Carrión, J. S.: A palaeoecological study in the western Mediterranean area: the Upper Pleistocene pollen record from Cova Benieto (Alicante, Spain), Palaeogeogr. Palaeocl., 92, 1-14, 1992a.

Carrión, J. S.: Late Quaternary pollen sequence from Carihuela Cave, south-eastern Spain, Rev. Palaeobot. Palyno., 71, 37-77, 1992 b.

Carrión, J. S. and Munuera, M.: Upper Pleistocene Palaeoenvironmental change in Eastern Spain: new pollen-analytical data from Cova Beneito (Alicante), Palaeogeogr. Palaeocl., 128, 287-299, 1997.

Carrión, J. S., Dupré, M., Fumanal, M. P., and Montes, R.: A Palaeoenvironmental study in semi-arid southeastern Spain: the palynological and sedimentological sequence at Perneras Cave (Lorca; Murcia), J. Archaeol. Sci., 22, 355-367, 1995.

Carrión, J. S., Fuentes, N., García, M. S., González-Sampériz, P., Finlayson, C., and Riquelme, J. A.: Pollen analysis of coprolites from Gorham's Cave depicts mosaic Pleistocene landscapes in Gibraltar, in: Cuaternario Mediterraneo y Poblamiento de Homínidos, edited by: Rodríguez Vidal, J., Finlayson, C., and Giles Pacheco, F., AEQUA, Madrid, 2005.

Courty, M. A. and Vallverdu, J.: The microstratigraphic record of abrupt climate changes in cave sediments of the Western Mediterranean, Geoarchaeology, 16, 467-500, 2001.

Dimitriadis, S. and Cranston, P. S.: An Australian Holocene climate construction using Chironomidae from a tropical volcanic maar lake, Palaeogeogr. Palaeocl., 176, 109-131, 2001.

Elias, S. A.: Late Tertiary and Early Quaternary, in: Encyclopedia of Quaternary Science, edited by: Elias, S. A., Elsevier, 2007.

Elias, S. A.: Advances in Quaternary Entomology, Developments in Quaternary Science, Elsevier Science, 12, 229-234, 2010.

Elwood, B. K., Petruso, K. M., Harrold, F. B., and Korkuti, M.: Paleoclimate characterization and intra-side correlation using magnetic susceptibility measurements: an example from Konispol Cave, Albania, J. Field Archaeol., 23, 263-271, 1996.

Engels, S. S., Bohncke, J. P., Heiri, O., and Nyman, M.: Intraregional variability in chironomid-inferred temperature estimates and the influence of river inundations on lacustrine chironomid assemblages, J. Paleolimnol., 40, 129-142, 2008.

Eggermont, H., Kennedy, D., Hasiotis, S. T., Verschuren, and D., Cohen, A.: Distribution of living larval Chironomidae (Insecta: Diptera) along a depth transect at Kigoma Bay, Lake Tanganyika: implications for palaeoenvironmental reconstruction, Afr. Entomol., 16, 162-184, 2008.

Erickson, J. M.: Fossil oribatid mites as tools for Quaternary paleoecologists: Preservation quality, quantities, and taphonomy, in: Late Pleistocene and Early Holocene Paleoecology and Archaeology of the Eastern Great Lakes Region, edited by: Laub, R. S., Miller, N. G., and Steadman, D. W., 33, 207-226, 1988.

Erickson, J. M. and Platt Jr., R. B.: Oribatid mites, in: Encyclopedia of Quaternary Science, edited by: Elias, A. S., Elsevier, 2007. 
Finlayson, G., Finlayson, C., Giles Pacheco, F., Rodriguez Vidal, J., Carrión, J. S., and Recio Espejo, J. M.: Caves as archives of ecological and climatic changes in the Pleistocene - The case of Gorham's cave, Gibraltar, Quatern. Int., 181, 55-63, 2008.

Ford, D. C. and Williams, P. W.: Karst geomorphology and hydrology, Unwin Hyman, London, 1989.

Ford, D. C. and Williams, P. W.: Karst Hydrology and Geomorphology, Wiley, Chichester, 2007.

Gandouin, E., Maasri, A., Van Vliet-Lanoë, B., and Franque, E.: Chironomid (Insecta: Diptera) assemblages from a gradient of lotic and lentic waterbodies in river floodplains of France: a methodological tool for paleoecological applications, J. Paleolimnol., 35, 149-166, 2006.

Gergócs, V. and Hufnagel, L.: Application of oribatod mites as indicators (review), Appl. Ecol. Env. Res., 7, 79-98, 2009.

Gulvik, M. E.: Mites (Acari) As Indicators of Soil Biodiversity and Land Use Monitoring: a Review, Pol. J. Ecol., 55, 415-440, 2007.

Haywood, A. M.: Pliocene climates, in: Encyclopedia of paleoclimatology and ancient environments, edited by: Gornitz, V., Springer, The Netherlands, 2009.

Holmes, J. A.: Ostracoda, in: Tracking Environmental Change Using Lake Sediments, Vol. 4, Zoological Indicators, edited by: Smol, J. P., Birks, H. J. B., and Last, W. M., Kluwer Academic Publishers, Dordrecht, 2001.

Horáček, I. and Bosák, P.: Special characteristics of paleokarst studies, in: Paleokarst. A Systematic and Regional Review, edited by: Bosák, P., Ford, D. C., Głazek, J., and Horáček, I., ElsevierAcademia, Amsterdam-Praha, 1989.

Horáček, I. and Ložek, V.: Palaeozoology and the Mid-European Quaternary past: scope of the approach and selected results, Rozpravy Československé akademie věd, řada matematických a přírodních věd, 98(4), 1-102, 1988.

Horáček, I., Mihevc, A., Zupan Hajna, N., Pruner, P., and Bosák, P.: Fossil vertebrates and paleomagnetism update one of the earlier stages of cave evolution in the Classical Karst, Slovenia: Pliocene of Črnotiče II site and Račiška pečina, Acta Carsologica, 37, 451-466, 2007.

Howard, L. C., Wood, P. J., Greenwood, M. T., and Rendell, H. M.: Reconstructing riverine paleo-flow regimes using subfossil insects (Coleoptera and Trichoptera): the application of the LIFE methodology to paleochannel sediments, J. Paleolimnol., 42, 453-466, 2009.

Korhola, A.: Distribution patterns of Cladocera in subarctic Fennoscandian lakes and their potential in environmental reconstructions, Ecography, 22, 357-373, 1999.

Korhola, A., Olander, H., and Blom, T.: Cladoceran and chironomid assemblages as quantitative indicators of water depth in subarctic Fennoscandian lakes, J. Paleolimnol., 24, 43-53, 2000.

Kukla, J. and Ložek, V.: To the problem of investigation of the cave deposits, Československý kras, 11, 19-83, 1958.

Kyrle, G.: Grundriss der theoretischer Speläologie, Österreichische Staatsdruckerei, Wien, 1923.

Lebrun, P. and van Straalen, N. M.: Oribatid mites: prospects for their use in Ecotoxicology, Exp. Appl. Acarol., 19, 361-379, 1995.

Lisiecki, L. E. and Raymo, M. E.: A Pliocene-Pleistocene stack of 57 globally distributed benthic $\mathrm{d}^{18} \mathrm{O}$ records, Paleoceanography, 20, PA1003, doi:10.1029/2004PA001071, 2005.
Luoto, T. P.: An assessment of lentic ceratopogonids, ephemeropterans, trichopterans and oribatid mites as indicators of past environmental change in Finland, Ann. Zool. Fenn., 46, 259-270, 2009.

Mihevc, A.: Fosilne cevke iz brezstrope jame - verjetno najstarejši ostanki jamskego cevkarja Marifugia (Annelida: Polychaeta). The fossilized tubes from the roofless cave - probably the oldest known remains of the cave worm Marifugia (Annelida: Polychaeta), Acta Carsologica, 29, 261-270, 2000.

Mihevc, A.: The age of Karst relief in west Slovenia, Acta Carsologica, 36, 35-44, 2007.

Mihevc, A., Sket, B., Pruner, P., and Bosák, P.: Fossil remains of a cave tube worm (Polychaeta: Serpulidae) in an ancient cave in Slovenia, Proc. 13th International Speleological Congress, 4th Speleological Congress of Latin America and the Caribbean, 26th Brazilian Congress of Speleology, Brasilia, 15-22 July 2001, 2, 20-24, 2001.

Norton, R. A. and Palmer, S. C.: The distribution, mechanisms, and evolutionary significance of parthenogenesis in oribatid mites, in: The Acari: Reproduction, Development and Life-History Strategies, edited by: Schuster, R. and Murphy, P. W., Chapman and Hall, London, 1991.

Panno, S. V., Curry, B. B., Wang, H., Hackley, K. C., Liu, C. L., Lundstrom, C., and Zhou, J.: Climate change in southern Illinois, USA, based on the age and $\delta 13 \mathrm{C}$ of organic matter in cave sediments, Quarternary Res., 61, 301-313, 2004.

Placer, L.: Contribution to the macrotectonic subdivision of the border region between Southern Alps and External Dinarides, Geologija, 41, 223-255, 1999.

Polk, J. S., van Beynen, P. E., and Reeder, P. P.: Late Holocene environmental reconstruction using cave sediments from Belize, Quaternary Res., 68, 53-63, 2007.

Polyak, V. J., Cokendolpher, J. C., Norton, R. A., and Asmerom, Y.: Wetter and cooler late Holocene climate in the southwestern United States from mites preserved in stalagmites, Geology, 29, 643-646, 2001.

Rautio, M.: Cladocera, in: Encyclopedia of Quaternary Science, edited by: Elias, A. S., Elsevier, 2007.

Robinson, M., Dowsett, H. J., and Chandler, M. A.: Pliocene role in assessing future climate impacts, EOS Transactions, 89, 501502, 2008.

Sasowsky, I.: Clastic sediments in caves - imperfect recorders of processes in karst, Acta Carsologica, 36, 143-149, 2007.

Sasowsky, I. D. and Mylroie, J. (Eds.): Studies of Cave Sediments. Physical and Chemical Records of Paleoclimate, Kluwer Academic/Plenum Publishers, New York, 2004.

Solhøy, I. W. and Solhøy, T.: The fossil oribatid mite fauna (Acari: Oribatida) in late-glacial and early-Holocene sediments in Kråkenes Lake, western Norway, J. Paleolimnol., 23, 35-47, 2000.

Solhøy, T.: Oribatid mites, in: Tracking Environmental Change Using Lake Sediments, Vol. 4. Zoological Indicators, edited by: Smol, J. P., Birks, H. J. B., and Last, W. M., Kluwer Academic Publishers, Dordrecht, 2001.

Smol, J. P.: Pollution of Lakes and Rivers: a Paleoenvironmental Perspective, Oxford University Press, Oxford, 2002.

Sroubek, P., Diehl J. F., Kadlec, J., and Valoch, K.: A Late Pleistocene palaeoclimate record based on mineral magnetic properties of the entrance facies sediments of Kulna Cave, 
Czech Republic, Geophys. J. Int., 147, 247-262, 2001.

Szeroczyńska, K. and Zawisza, E.: Daphnia remains from the sediments of lake Somaslampi (NW Finnish Lapland) and Lake Wigry (NE Poland), Studia Quaternaria, 22, 55-57, 2005.

Taylor, A. R. and Wolters, V.: Responses of oribatid mite communities to summer drought: The influence of litter type and quality, Soil Biol. Biochem., 37, 2117-2130, 2005.

Turney, C. S. M., Bird, M. I., and Roberts, R. G.: Elemental $\delta 13 \mathrm{C}$ at Allen's Cave, Nullarbor Plain, Australia: assessing postdepositional disturbance and reconstructing past environments, J. Quaternary Sci., 16, 779-784, 2001.

Vrabec, M. and Fodor, L.: Late Cenozoic tectonics of Slovenia: structural styles at the Northeastern corner of the Adriatic microplate, in: The Adria microplate: GPS geodesy, tectonics and hazards, edited by: Pinter, N., Grenerczy, G., Weber, J., Stein, S., and Medak, D., NATO Science Series, IV, Earth and Environmental Sciences, Springer, Dordrecht, 151-168, 2006.

Walker, I. R.: Chironomid overview, in: Encyclopedia of Quaternary Science, edited by: Elias, A. S., Elsevier, 2007.
Walker, R.: Midges: Chironomidae and related Diptera, in: Tracking Environmental Change Using Lake Sediments, Vol. 4, Zoological Indicators, edited by: Smol, J. P., Birks, H. J. B., and Last, W. M., Kluwer Academic Publishers, Dordrecht, 2001.

White, W. B.: Cave sediments and palaeoclimate, J. Cave Karst Stud., 69, 76-93, 2007.

Zupan Hajna, N., Mihevc, A., Pruner, P., and Bosák, P.: Cave sediments from the Postojnska-Planinska cave system (Slovenia): evidence of multiphase evolution in epiphreatic zone, Acta Carsologica, 37, 63-86, 2008a.

Zupan Hajna, N., Mihevc, A., Pruner, P., and Bosák, P.: Palaeomagnetism and Magnetostratigraphy of Karst ediments in Slovenia, Carsologica, 8, Založba ZRC, Ljubljana, 2008b.

Zupan Hajna, N., Mihevc, A., Pruner, P., and Bosák, P.: Palaeomagnetic research on karst sediments in Slovenia, Int. J. Speleol., 39, 47-60, 2010. 